\title{
Advantages of implementing organic farming methods in agricultural lands
}

\author{
Jedd Moore \\ Mount Vernon, Ohio
}

Bachelor of Arts in Environmental Sciences, University of Virginia, 2012

A thesis presented to the Graduate Faculty of the University of Virginia in candidacy for the degree of Master of Arts

Department of Environmental Sciences

University of Virginia

August 2013 


\begin{abstract}
Globally, the most prevalent type of farming systems use resource intensive methods and are referred to as conventional agriculture. While this type of agricultural system is responsible for providing crops for the majority of the world's food and biomaterials, there are consequences that come with the high production. The heavy use of fossil fuels, synthetic nitrogen, and other chemical applications have been linked to soil degradation, reduced biodiversity, and pollution on farmlands. The environmental costs associated with conventional agriculture have been an issue of concern, and I believe that organic farming is a viable alternative that can help supply the world's caloric needs with less damage to our environment.

Organic farming is a production system that conforms to site-specific conditions by combining biological and mechanical practices that encourage cycling of resources, ecological balance, and conservation of biodiversity. Regulations of organic farming prohibit the use of synthetic fertilizers, pesticides, and genetically modified organisms. Instead, the system relies on biological nitrogen fixation, crop rotations, and cover crops to maintain soil fertility and to manage weeds, insects and diseases. Comparisons between organic farming systems using best management practices and conventional farming systems often reveal differences in many aspects. Soil properties of soil organic matter, nitrogen, and biodiversity have all been reported to be superior among organically managed systems. The amount of fossil fuel use is often significantly less in organic agriculture due to restrictions on chemical and synthetic applications. Yields between the two systems are often
\end{abstract}


heavily debated, and can have high variance regionally. However, under proper conditions and management practices, yields are often comparable, but still less on average than when compared to conventional farming.

Much still needs to be done in terms of research and development for both organic and conventional farming. There has been noticeably more financial support and research conducted on conventional agriculture, but if organic agriculture is going to be seen as viable alternative, it will need the same, or more economic backing than conventional has received. Organic farming has the potential to play a larger role in our agricultural system and can aid in enhancing the naturalresource base and environment of agricultural lands through the advantages of organic farming methods. 


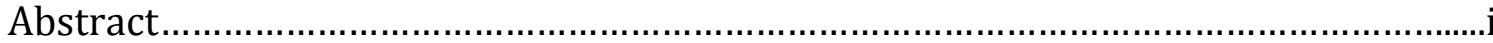

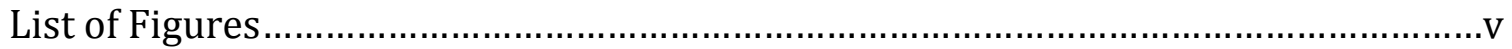

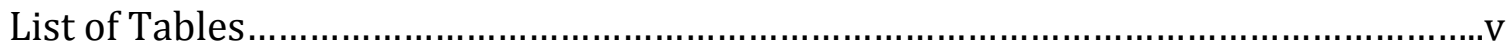

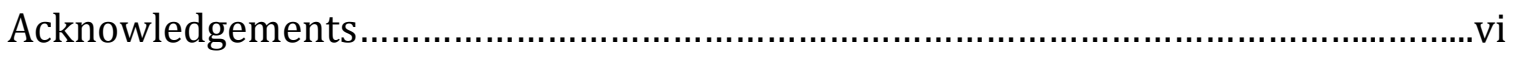

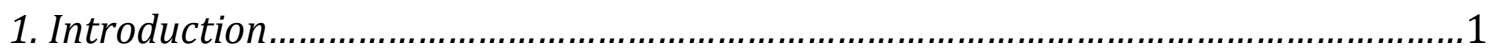

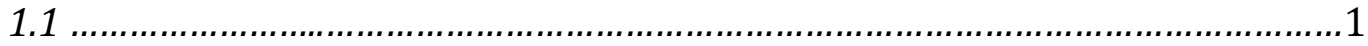

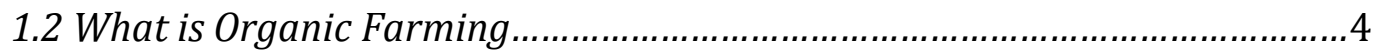

2. Benefits of Organic Farming: Soil Properties............................................................

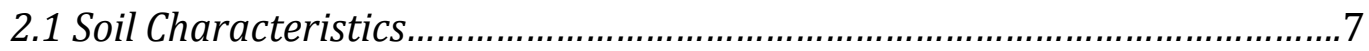

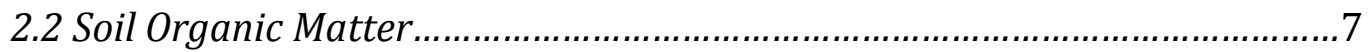

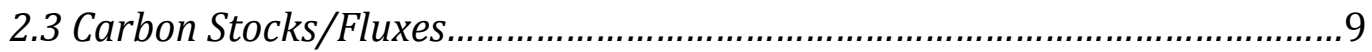

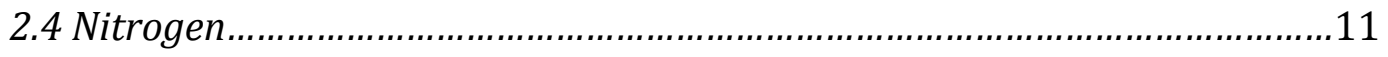

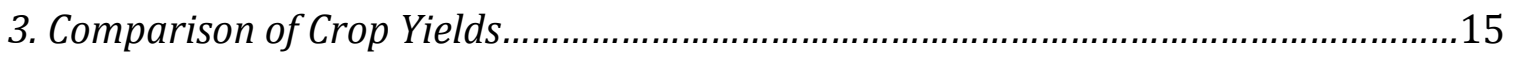

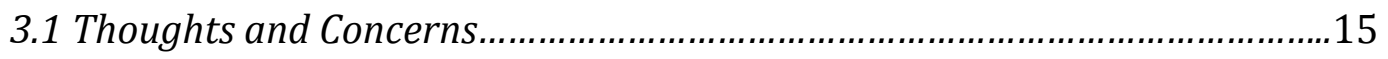




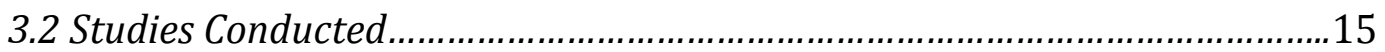

3.3 Developed and Undeveloped Countries.....................................................17

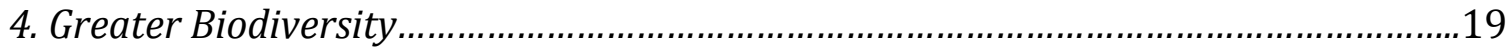

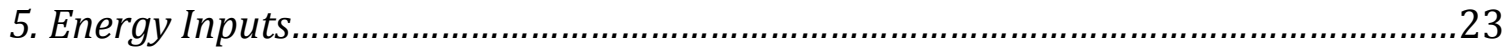

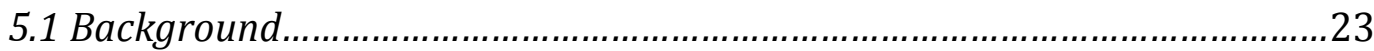

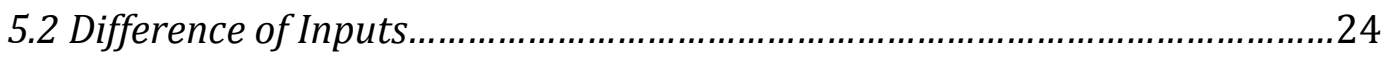

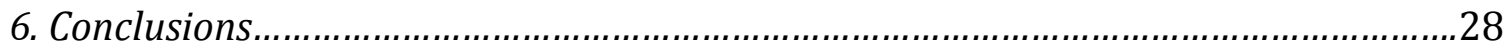

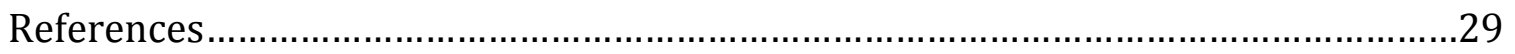




\section{LIST OF FIGURES}

Figure 1. Global agricultural land use...........................................................

Figure 2. Examples of organic and conventional management practices................6

Figure 3. Comparison of soil organic matter between farming systems..................9

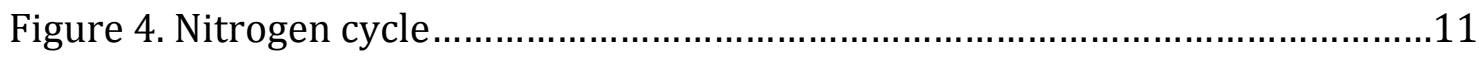

Figure 5. Comparison of soil nitrogen between farming systems ............................13

Figure 6. Importance of release of nutrient uptake by plants.................................14

Figure 7. Influence of different crop types, plant types and species on

organic-to-conventional yield ratios........................................................16

Figure 8. Sensitivity study of organic-to-conventional yield ratios.........................18

Figure 9. Multivariate and interacting nature of farming practices and some of the routes by which farming practice impacts on farmland birds............20

Figure 9. Average energy inputs between corn and soybeans systems....................26

\section{LIST OF TABLES}

Table 1. Summary of the effects of organic farming on individual taxon in comparison to conventional 


\section{ACKNOWLEDGEMENTS}

I thank my graduate advisor Steve Macko for the lessons he has taught me this past academic year. Also for guiding and supporting me in completing my degree.

I thank my committee members Howie Epstien and Randy Bird, who were very helpful in giving me direction on research and commenting on my draft.

I thank my family for always being there for me throughout my ventures and continuous support.

I thank the University of Virginia for the education and resources that it has provided me and countless others. 


\section{Introduction}

1.1

The production and yields of the world's major crops have increased dramatically over the last 70 years as a direct result of developments in modern, resource-intensive agricultural practices. This type of modern agriculture is referred to as conventional farming, and is currently the most prevalent type of farming, covering 4.9 Gha of agricultural land (Figure 1.) (Leifeld, 2012). While conventional farming has provided large populations with food, it has not come without costs. The increases in production have come at the expense of intensely debated environmental costs such as high fossil fuel and chemical inputs, nutrient loss, soil degradation, and decreased biodiversity due to the large monocultures created. As the effects of standard conventional agriculture practices come to light, there has been a growing demand for environmentally "green" or chemical free food products (Horlings and Marsden, 2011). Because of the toll conventional farming puts on the environment, many question whether or not this type of agriculture is the best approach to continue using in the generations to come. Organic farming has been suggested as an alternative to conventional farming due to its lower environmental costs. 


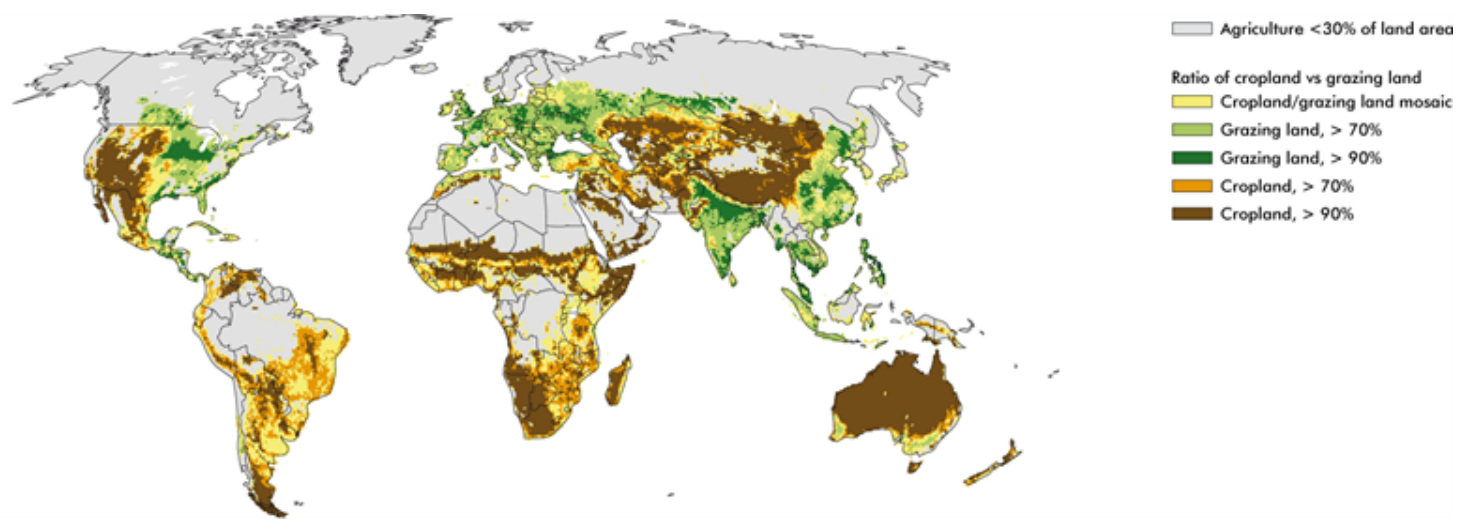

Figure 1. Global agricultural land use. Source: Ahlenius, (2006).

The United States Department of Agriculture's National Organic Program (2002) defines organic agriculture as a "productions system that...respond[s] to site-specific conditions by integrating cultural, biological, and mechanical practices that foster cycling of resources, promote ecological balance, and conserve biological biodiversity." ${ }^{1}$ The use of synthetic fertilizers, pesticides, and genetically modified organisms are prohibited, so the system relies on biological nitrogen fixation, crop rotations, and cover crops to maintain soil quality and to manage weeds, insects, and diseases. While organic farming may seem to have less negative impacts to the environment and be more "green," the downside to it is that it is usually more laborintensive to manage and generally produces lower yields when compared with averages of conventional farming (Ziesemer, 2007; Reganold, 2012). Along with the lower yields for some crops, the current organic agricultural land takes up about 0.037 Gha, which still significantly less than the conventional farming that has been built into our food production infrastructure over the years. Owing to the restrictions on inputs into the system, especially fertilizers, there is a question as to

1 Pamela Coleman, Guide for Organic Crop Producers. (United States Department of Agriculture, 2012). 
whether or not this type of system is sustainable (i.e. able to maintain an ecological balance by not depleting our natural resource base) over the long term. Another question regarding the sustainability has to do with our food supply. Because of the lower yields, some have estimated that organic farming may need between 16 and 100 percent more land area compared to high-input conventional agriculture (Leifeld, 2012). With the global human population currently at about 7 billion (U.S. Census Bureau, 2013 and projected to rise to 8 billion by 2025 (U.S. Census Bureau) , the need to be as efficient (i.e. for a given land area getting the most output per input of resources) as possible with the land we have will be more important than ever.

Being efficient with our land and resources will be of the utmost importance, but so will maintaining the quality of our lands while reducing the negative impacts to our planet for future generations. Both conventional and organic farming have upsides and downsides with their management practices, results, and impacts on the environment. In order to meet the requirements for food production and maintain healthy environments, relying on just one system alone may not be sufficient (Reganold, 2012). If organic farming can produce similar yields with some crops under certain environments, then there should be more incentives to let farmers grow as organic as possible where they can. There is no question that the amount of food produced by conventional farming will be hard to match, however, organic farming provides multiple sustainability benefits and can be a contributing factor to our agriculture system (Reganold, 2012). With less than one percent of agriculture land being managed organically (Willer, 2011) there is a large amount 
room for growth in this type of farming. The U.S. National Research Council (2010) describes the four main goals of agriculture to be sufficient productivity, enhancing the natural-resource base and environment, making farming financially viable, and contributing to the well-being of farming and its communities (Dobermann, 2012). Conventional farming meets the criterion for the first goal of productivity but lacks improvement in the remaining three goals, especially when considering the enhancement of our natural-resource base and environment. When considering the

on farm systems, both methods of farming have their benefits and shortcomings, but there are multiple aspects in which organic farming methods are advantageous when compared to conventional. Growth in the organic sector can aid in enhancing the natural-resource base and environment of agricultural land, helping to fulfill requirements of agriculture. Organic farming is not only able to contribute to the supply of current and future populations with food, it is also capable of maintaining a healthy environment in doing so.

\subsection{What is Organic Farming?}

There are many different definitions of organic farming; the one provided by the International Federation of Organic Agriculture Movement (2008) is:

"Organic agriculture is a production system that sustains the health of soils, ecosystems and people. It relies on ecological processes, biodiversity and cycles adapted to local conditions, rather than the use of inputs with adverse effects. Organic agriculture combines tradition, innovation and science to 
benefit the shared environment and promote fair relationships and a good quality of life for all involved."2

The objective of this type of agriculture is to produce a more balanced food system through connecting natural biological and ecological processes. The practices of organic farming are strict, and are codified by law (Rigby and Caceres, 2001). In fact, the regulations instilled in organic farming are what set it apart from other practices. There are certification procedures that range from the soil on which the plant is grown, what inputs are applied to the farming system, and to how finished product is processed. While there are certification standards that must be followed, farmers also have the ability to boost the ecological and sustainable practices of their farms beyond what the standards require as much as they deem necessary (Ziesmer, 2007).

Organic farming highlights the use of management practices in preference to the use of off-farm inputs, while taking into account that regional conditions require locally adapted systems (Ziesemer, 2007). In organic farming, crop production relies largely on closed nutrient cycles (i.e. using least amount of off farm inputs as possible) by returning plant residues and manure back to the soil and by incorporating perennial plants, such as grass-clover mixtures and legumes, into the system (Gattinger et al. 2012). Typical methods of organic farming vary, but commonly include crop rotation (used for nitrogen fixation), organic manures from livestock and compost (used for nitrogen and other nutrients), biological pest

\footnotetext{
2 International Federation of Organic Agriculture Movements, Organic Agriculture for the real Green Revolution in Africa (2008), www.ifoam.org/about_ifoam/principles/index.html
} 
control (in the form of natural insect predators), and mechanical cultivation (i.e.

tilling) (Figure 2.). Genetically modified plants produced through engineering are not used, but rather plants that are generated via plant breeding are selected.

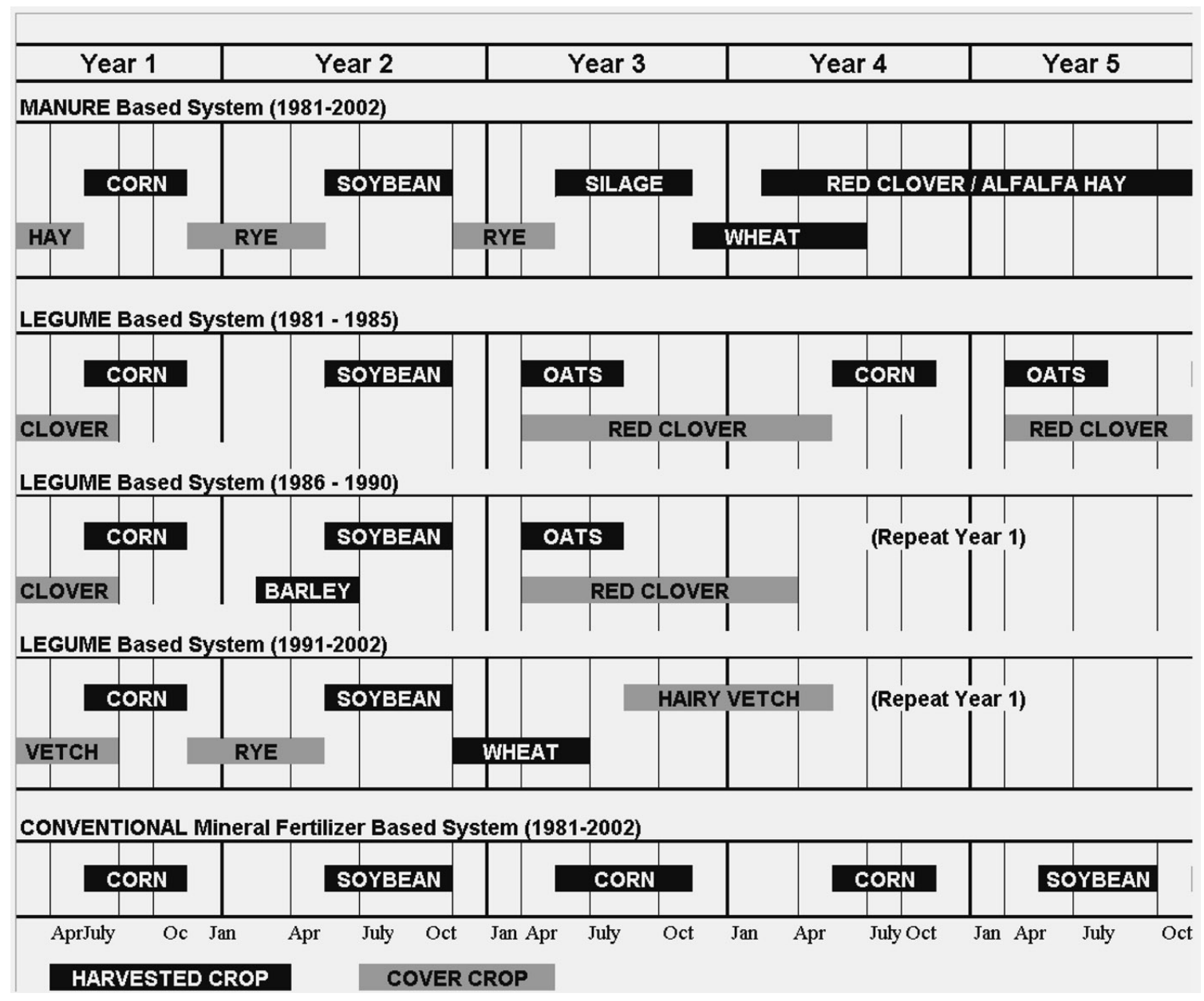

Figure 2. Example of different crop rotations used in organic and conventional farming. Source: Hepperly et al. (2007). 


\section{Benefits of Organic Farming: Soil Properties}

\subsection{Soil Characteristics}

Soils in organic systems have been associated with favorable characteristics over time when managed properly. Levels of soil organic matter, water-holding capacity, pH stabilization, low bulk density, essential nutrients are either increased or generally superior over time when compared to soil from conventional farming systems, and under proper management. Researchers have generally found that the application of organic amendments, inclusion of forage legumes in crop rotations, and less frequent tillage tend to increase levels of organic carbon and nitrogen. The same applies for more labile indicators, such as microbial biomass, particulate organic matter, and mineralizable carbon and nitrogen (Coulter, 2009).

\subsection{Soil Organic Matter}

Soil organic matter is any previous living material that is returned to the soil and then undergoes decomposition (Bot and Benites, 2005). It plays several key functions of the soil such as providing nutrients for plants, binding soil aggregates together, and improving the water holding capacity. Without maintenance of the soil organic matter, both nutrient cycling and soil productivity declines, which in turn has effects on the growth of plants. This is especially prevalent under stressful conditions, such as a drought during which water becomes the most limiting nutrient rather than a nutrient such as nitrogen. Many common farming practices 
such as tilling and plowing accelerate the loss of soil organic matter by leaving the soil susceptible to wind and water erosion and decomposition. Organic farming methods of no tilling, minimal tilling, and cover crop rotations help to conserve and promote soil organic matter. Being mindful of replenishing nutrients in an effective way that does not hurt the soil composition is important as the soil is mined during harvest.

The measure of carbon content in the soil is one indication of organic matter and overall soil health. In a study conducted by the Hepperly et al. (2007), soil carbon levels in 1981 among the organic manure, organic legume, and conventional systems were not different $(p=0.05)$. By 2002 , the soil carbon increased by 28,15 , and $9 \%$ for the manure, legume, and conventional systems, respectively, showing significant increases in soil quality over time(Figure 3.) (Hepperly et al. 2007). In a similar study conducted by Wortman et al. (2011) soil fertility among conventional and organic cropping systems of corn, sorghum, and soybean were compared between 1996 and 2007. Averaged over the 11 years, soil organic matter was greater in the farms that were managed using organic methods at $3.84 \%$ when compared to the conventional treatment at 3.27\% (Wortman et al. 2011). Marriot and Wander (2006) reported in a summary of trials across the United States that organic systems using manure plus legumes, and a separate legumes only, both saw an increase of $14 \%$ in soil organic carbon over a ten year average. These findings demonstrate that organic farming systems are able to retain high nutrient levels over extended periods of time. This is also notably shown by Drinkwater et al. (1998) and Maeder et al. (2002) in their 15 and 21 year trials, respectively, where 
nutrient inputs were either less or similar for organic systems than conventional, and still reported higher levels of total organic carbon. Another benefit associated with having higher soil organic matter content is decreased irrigation requirements, because the soil has superior water retaining abilities (Fan et al. 2005).

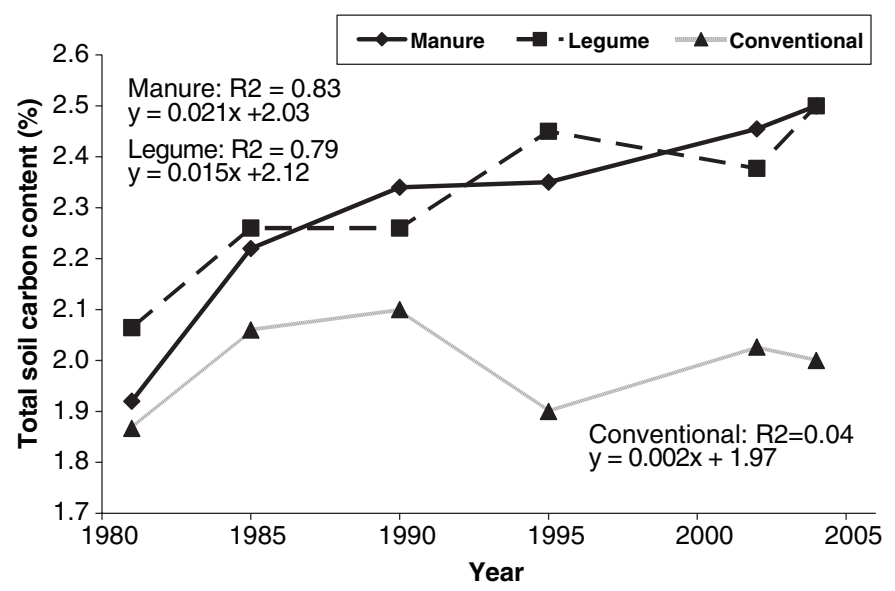

Figure 3. Linear regression of time under three farming systems (organic animalbased cropping, organic legume-based cropping, and conventional cropping) from The Rodale Intitute Farming Systems Trial to total soil carbon content. Source: Hepperly et al. (2007).

\subsection{Carbon Stocks/Fluxes}

The sequestration of atmospheric carbon in soil organic matter is a large factor when considering climate change and greenhouse gases. Carbon dioxide is the most significant greenhouse gas directly affected by anthropogenic activities, and is emitted to the atmosphere most notably via combustion of carbon-based fuels or the decay of biomass. Natural sources of carbon dioxide being emitted into the air are from forest fires, volcanic eruptions, and respiration of organic matter in 
the land based environment as well as the oceans. Use of fossil fuel and deforestation/land use change in the form of creating urban environments and clear cutting forests are the most significant anthropogenic contributors of carbon dioxide into the atmosphere. These anthropogenic actions release already stored carbon (organic matter) and reduce the natural ability of ecosystems to sequester and store carbon. Historically, global carbon stocks of agricultural land have been reported as decreasing and continue to do so (Lal, 2004). Therefore, using farming methods that could potentially reduce carbon loss or even improve carbon stores in the soil are becoming more appealing (Gattinger et al., 2012).

In a study conducted by Gattinger et al. (2012), datasets from 74 studies comparing organic versus conventional farming systems were subjected to examination to determine differences in soil organic carbon. In this study, the results of the comparisons between farming systems showed significantly higher soil organic concentrations, soil organic carbon stocks, and carbon sequestration rates in the organic top soils. The authors also found that the main differences found among the soil organic carbon levels were predominantly influenced by the organic practices of mixed farming, such as crop rotations and organic matter recycling. Converting to these types of farming practices in environments where they have shown to be the most effective could potentially have mitigation effects for greenhouse gas emissions from the release of carbon dioxide into the atmosphere. 


\subsection{Nitrogen}

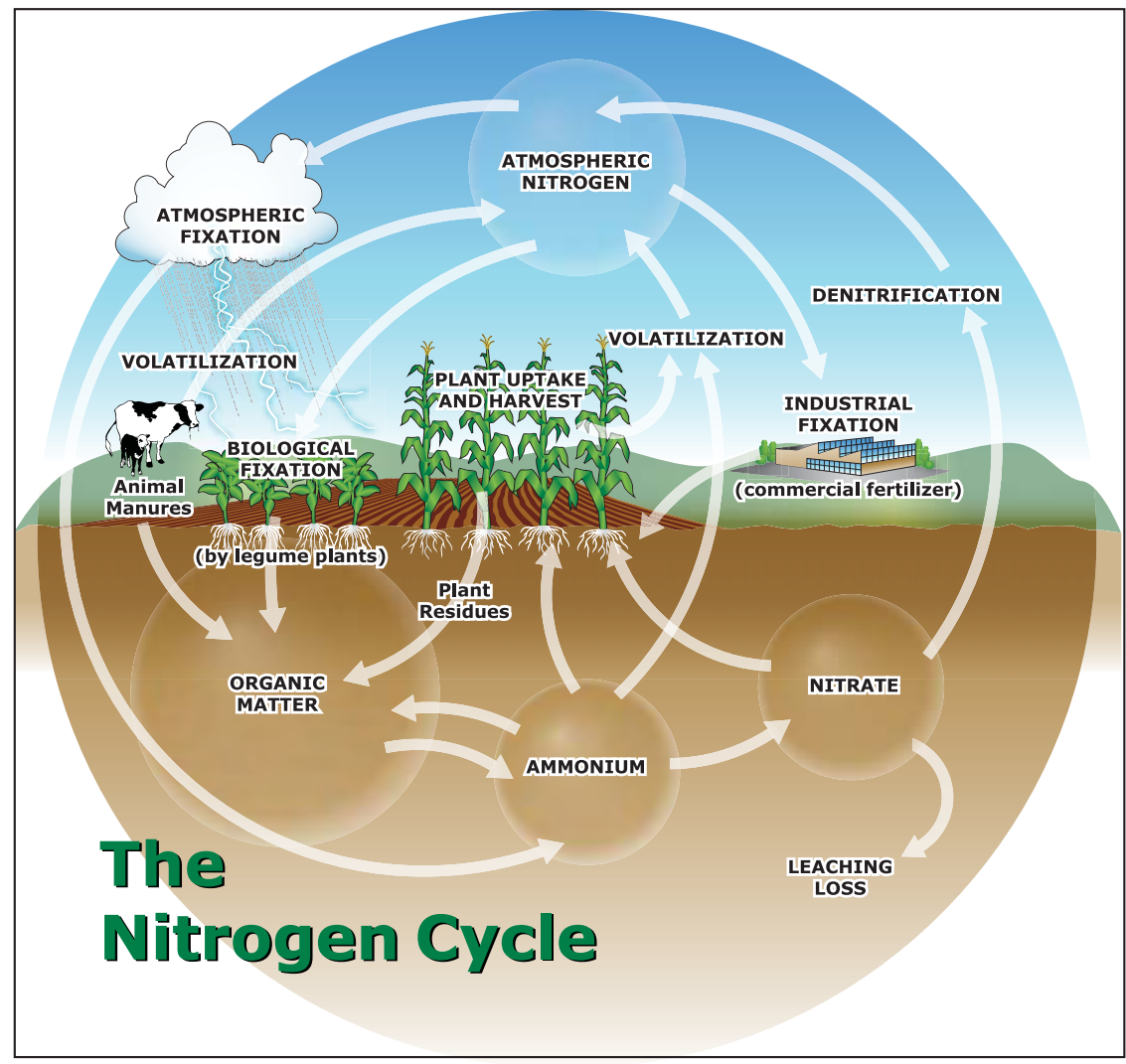

Figure 4. Nitrogen cycle incorporating both organic and conventional inputs to the farming system. Organic nitrogen is converted to various inorganic nitrogen forms prior to plant uptake. Source: Mikkelsen and Hartz (2008).

Soil nitrogen content is another indicator of both soil fertility (productivity), and in many systems it is a factor that can limit yields and productivity (Ching, 2002). Nitrogen is an important building block of proteins and nucleic acids, and is essential for all forms of life. Because nitrogen is lost during harvesting and other processes, constant replenishment is essential during the cash crop season (crops used for direct sales rather than for livestock feed) and the intermittent seasons (Figure 4). Nitrogen is quite abundant in the atmosphere making up about $79 \%$ of air, however; only certain organisms can use or "fix" atmospheric nitrogen, such as 
leguminous plants (e.g. soybeans, clover, alfalfa) that have a symbiotic relationship with rhizobium bacteria that inhabit the roots. (0'Leary et al. 2002). In organic systems, nitrogen is usually sourced from livestock manures where the animals are certified organic, and by nitrogen fixing plant cover crops in the off-season. Using these methods of nitrogen input have shown to significantly increase total nitrogen in the soil when compared to only using synthetic nitrogen fertilizers (Figure 5.) (Omokanye et al. 2011; Hepperly et al. 2007; Marriott and Wander, 2006; Wortman et al. 2011). The inclusion of legumes in cropping systems has also shown to increase efficiency of nitrogen use by the crops, as long as there is not competition between the crop and legume for soil moisture.

Plants need certain quantities of nitrogen, and increasing the amounts applied to the fields will increase productivity, but the plants can only use so much of the nitrogen. So what happens to the excess? In a report by the United Nations Environment Programme (Sutton et al. 2013), excessive fertilizer use can contribute to "a growing pollution web requiring urgent action" (Merberg, 2013). The report continues to explain that excess nitrogen that is not used by the crops is responsible for many adverse effects to the environment, such as algal blooms and dead zones, contaminated drinking water, air pollution, climate change, and loss of biodiversity. Synthetic fertilizers are in a very soluble form so that the plants can readily take them up, but this also leads to more excess leaching when compared to typical organic nitrogen input methods (Hepperly et al. 2007). 


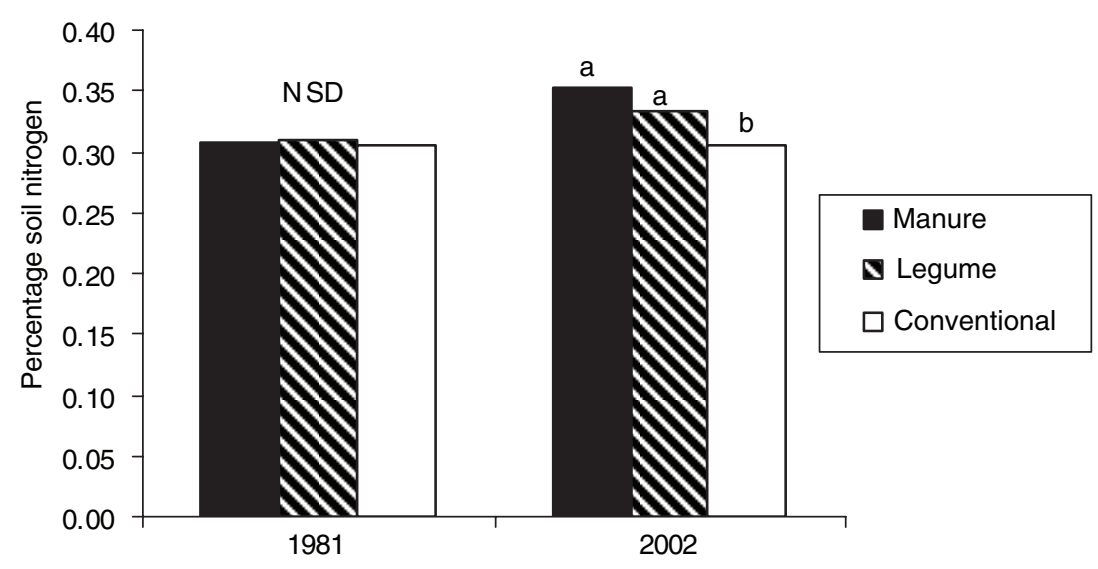

Figure 5. Percentage of soil nitrogen for the three systems (organic animal-based cropping, organic legume-based cropping, and conventional cropping) of the Rodale Institute Farming Systems Trial in 1981 and 2002. Different letters indicate statistically significant differences according to Duncan's multiple range test; $\mathrm{p}<0.05$. NSD $=$ not significantly different. Source: Pimentel et al. (2005).

Choosing the correct amount of nitrogen to add to a system, and from which sources, is a difficult task and will change under different environmental conditions, such as local temperatures and soil compositions. The most suitable source of any nitrogen fertilizer, whether from organic or inorganic sources, will depend on nutrient ratios, plant-available nitrogen, mineralization rates, local accessibility, ease of application, and environmental and monetary costs. Failure to coordinate crop uptake with nitrogen mineralization can bring about "plant nutrient deficiencies, excessive soil nitrogen beyond the growing season, and the potential for excessive nitrate leaching (Figure 6.). Application of the fertilizer must consider many of these options in order be as productive as possible under the circumstances while at the same time being mindful of the adverse effects of adding excessive amounts. 


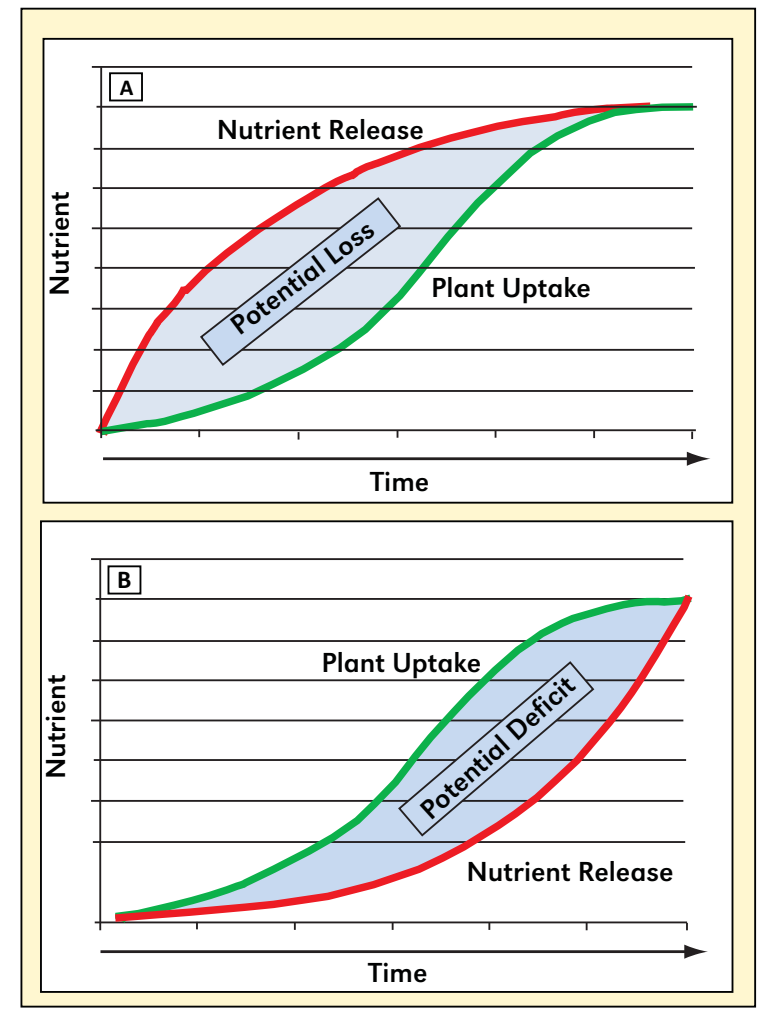

Figure 6. The importance and difficulty of coordinating nutrient release with plant demand. Rapid release form organic sources with a low carbon:nitrogen ratio may supply nutrients more rapidly than the plant's demand (A). An organic material with a high carbon:nitrogen ratio may not release nutrients sufficiently rapid to meet the need of growing plants (B). Source: Mikkelsen and Hartz (2008). 


\section{Comparison of Crop Yields}

\subsection{Thoughts and Concerns}

One of the greatest concerns when comparing organic to conventional farming is the yield, that is the measure of crop per unit area of land cultivated (usually measured in tons per hectare). This is a topic of much debate because in order for agriculture to be sustainable it has to be able to support our current and future demands for food and other byproducts from crops using the finite land we have on the planet. It is generally thought that going organic means a drastic decrease in crop yields, but this is not the case when proper techniques are used for site-specific areas. In order to fully analyze comparisons of organic versus conventional yields, long-term studies measuring multiple variables must be used. This is because when a farming system initially switches over to organic agriculture, it takes about three years for the system to adjust and to see increases in yields (Ching, 2002).

\subsection{Studies Conducted}

Seufert et al. (2012) conducted a global meta-analysis covering 66 studies and 316 yield comparisons showing that organic farming systems in developed countries produced yields that were $20 \%$ lower when compared to conventional farming (Reganold, 2012). However, along with these findings, Seufert et al. (2012) also found that with certain crops, management practices, and growing conditions, 
the yields were comparable with conventional methods. Several studies (Hepperly et al., 2007; Posner et al., 2008; Porter et al., 2003) have reported that organic crop yields were very similar to those of conventional yields under proper methods and for certain plant species. Among the highest-yielding organic crops reported by Seufert et al. (2012), were certain fruits (3\% lower yields), rain-fed legumes (5\% lower yields), and oilseed crops (11\% lower yields) (Figure 7.). Others (e.g. Badgley et al., 2007) found the best yielding organically grown crops to be rice (6\% lower yields), soy beans (8\% lower yields), corn (11\% lower yields), and grass clover (11\% lower yields) (Reganold, 2012).

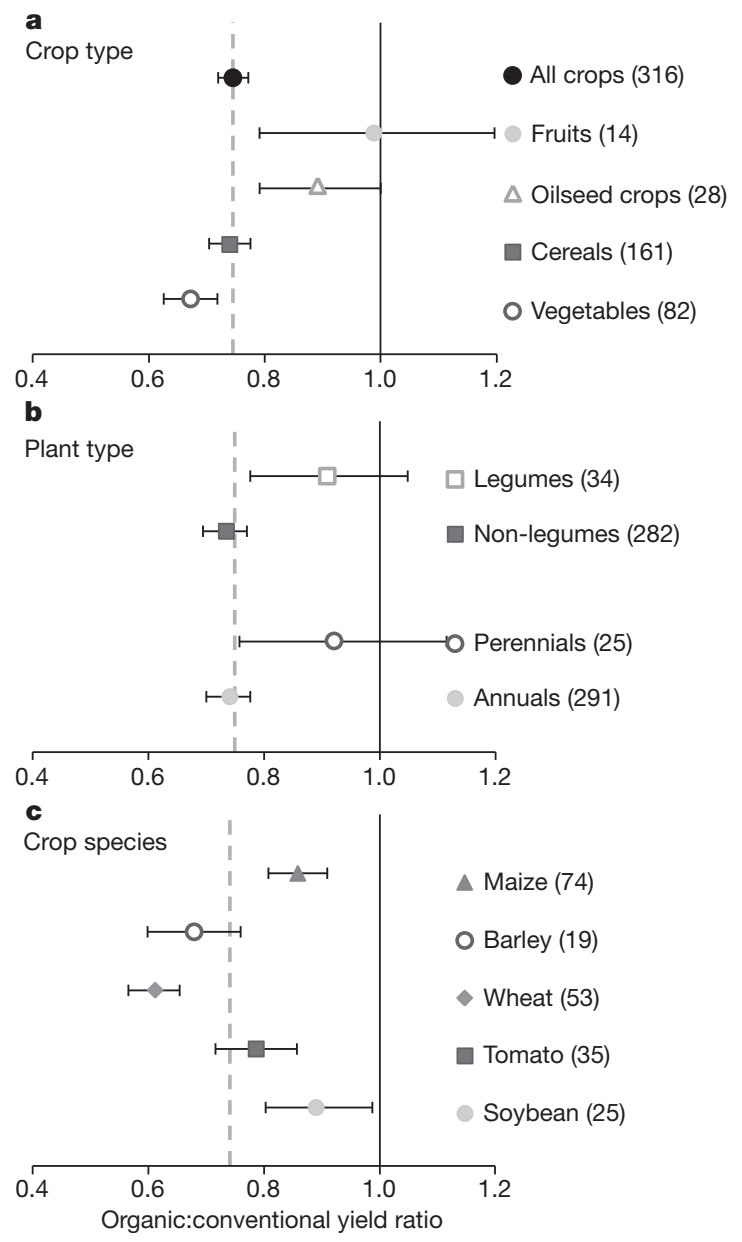


Figure 7. Influence of different crop types, plant types and species on organic-to-conventional yield ratios. Influence of crop type (a), plant type (b), and crop species (c) on organic-to-conventional yield ratios. The number of observations in each class is shown in parentheses, and the dotted line indicates the cumulative effect size across all classes. Source: Seufert et al. (2012).

A review (Liebhardt, 2001) of the results of seven different Universities in the United States during a 10-year study from the Rodale Research Center, Pennsylvania and the Michael Fields Center, Wisconsin showed comparable yields between organic and conventional agriculture (Ching, 2002). Comparisons of corn, covering 69 cropping seasons, revealed that organic yields were 94\% when measured up to conventional yields. Data from soybean fields covered 5 different states and a total of 55 , and growing seasons had organic yields averaging $94 \%$ of conventional yields. Wheat was compared across 16 cropping year experiments and resulted in yields that were $97 \%$ of the conventional yields. Tomatoes showed no difference in yields over a 14-year study between organic and conventional farming methods (Ching, 2002).

\subsection{Developed and Undeveloped Countries.}

Perhaps the largest potential for increases in crop yields can be seen in smaller farms in developing countries that have drastically lower production and yields when compared to developed countries. This is often due to the lack of technology, resources, and financial support. However, when compared to current production in developing countries, the incorporation of intensive agroecological techniques commonly used in organic farming, such as crop rotations, cover 
cropping, application of organic fertilizers, and more efficient water management can significantly increase production. Case studies from multiple developing countries have been switching to these types of practices and have noticed drastic changes by using many different practices in certain locations. The uses of green manures and cover crops for maize in Brazil have seen increases in yields from 20 to $250 \%$ of current production (Parrott and Marsden, 2002). In Santa Caterina, Brazil the use of contour grass barriers, contour plowing, crop rotations/cover crops, and green manures on about 60 crop species has led to tremendous changes in the farming system. The yields for maize and soybeans are reported to have increased by $66 \%$ along with increases in soil quality, water retaining capacity, and biological activity (Parrott and Marsden, 2002). In Madhya, Pradesh, India, cotton yields on participating farms were on average $20 \%$ higher than on neighboring farms using conventional methods during a seven year study. Sugar cane yields were also $30 \%$ higher when compared to conventional yields and also were reported as having a higher sugar content, which obtained higher price premiums during the seven years of the study. (Parrott and Marsden, 2002).

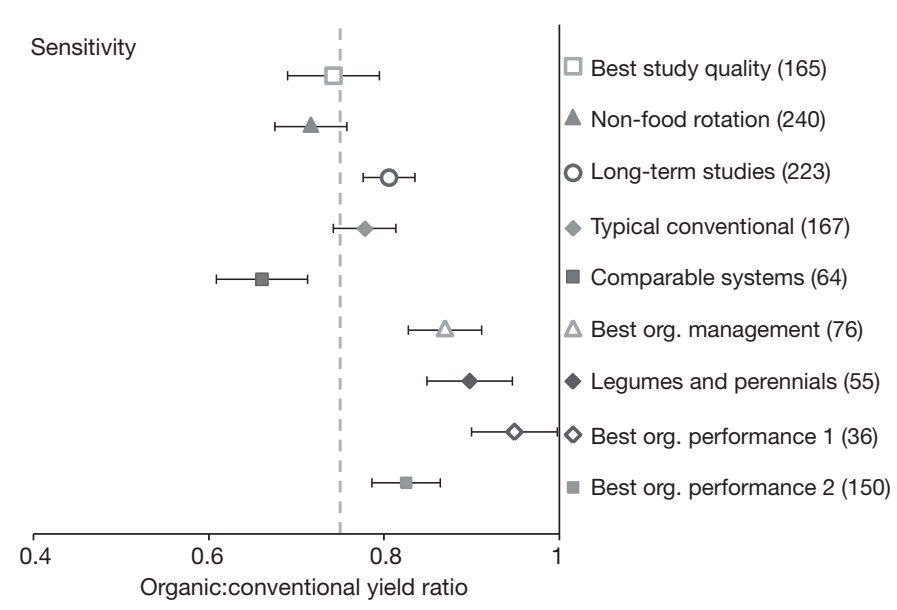


Figure 8. Sensitivity study of organic-to-conventional yield ratios. Best study quality (peer-reviewed studies using appropriate study design and making appropriate inferences); non-food crop rotation; long-term studies (excludes very short duration and recently converted studies); typical conventional (restricted to commercial conventional systems with yields comparable to local averages); comparable systems (studies that use appropriate study design and make appropriate inferences, where both systems have the same non-food rotation length and similar nitrogen inputs); best organic management (excludes studies without best management practices or crop rotations); legumes and perennials (restricted to leguminous and perennial crops); best organic performance 1 (rain-fed legumes and perennials on weak-acidic to weak-alkaline soils); best organic performance 2 (rainfed and weak-acidic to weak-alkaline soils). Values are mean effect sizes with $95 \%$ confidence intervals. The number of observations is shown in parentheses. The dotted line indicates the effect size across all studies. Source: Seufert et al. (2012).

It is important to note that these studies differ, because no single farming practice or system structure is the most efficient in every location. These studies do encourage the argument that using organic agriculture under conditions in which it performs best will help to close the yield gap between organic and conventional farming systems, and increase organic farming's role in our food supply (Figure 8).

\section{Greater Biodiversity}

Intensification of agriculture has led to an overall decline in farmland biodiversity that ranges across many taxa (Benton et al. 2003), largely in part to the use of pesticides, herbicides and creating large monocultures (Hole et al. 2005). For example, evidence has been shown in the United Kingdom that ten native birds species to farmlands have declined by as much as ten million breeding pairs (Krebs et al., 1999), which is a decline of 83 percent from 1970-1990 (Figure 9.) (Fuller et 
al., 1995). Other taxa such as mammals, arthropods, and flowering plants, have been reported as having similar declines in biodiversity as well (Benton et al. 2005).

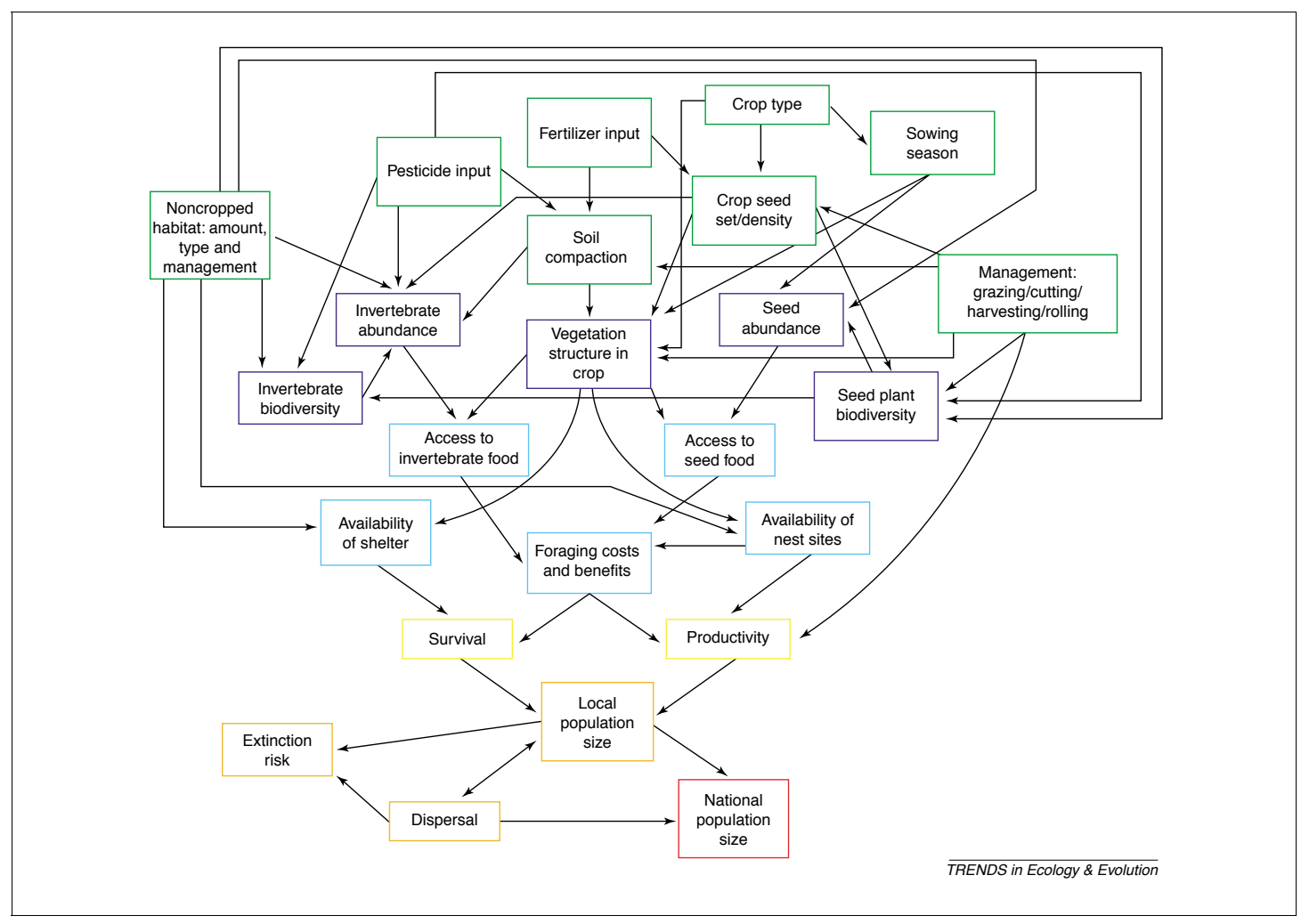

Figure 9. Multivariate and interacting nature of farming practices and some of the routes by which farming practice impacts on farmland birds. Arrows indicate known routes by which farming practices (green boxes) indirectly (dark-blue boxes) or directly ( light-blue boxes) affect farmland bird demography (yellow boxes) and therefore local population dynamics (orange boxes) and total population size (red boxes). Source: Benton et al. (2003).

There are also tremendous amounts of living organisms in the soil that accumulate and form complex relationships with the farm ecosystem. The organisms in the soil can vary from microscopic organisms such as bacteria and fungi, to visible macro-fauna such as earthworms and termites. The presence of such biological activity is affected by the environmental factors of temperature, soil $\mathrm{pH}$, and moisture, all of which largely reflect farming management practices. Soil 
organisms contribute many necessary services, as they are the primary driving agents of nutrient cycling, regulation of soil organic carbon, and nutrient acquisition efficiency by the plants (Scialabba, 2003). Managed properly, abundant biodiversity can aid in crop protection in the form of disease reduction as well (Cook, 1988; Hoitink, et al., 1991). The management practices of crop rotations, green manure and cover crops, minimum tillage, and the absence of herbicides and pesticides are all used heavily in organic agriculture and contribute to increased soil biodiversity (Pimentel 1992; Maeder et al 2002; Hepperly et al. 2007). The Rodale Institute Farming Systems Trial, which reported higher arbuscular mycorrhizae colonization, great number of arbuscular mycorrhizae spores, and higher soil respiration rates in the organic manure and organic legume systems when compared to the conventional system supported this (Hepperly et al., 2007). An abundance of arbuscular mycorrhizae is beneficial due to their ability to help plants capture nutrients such as nitrogen and also micronutrients from the soil. The primary difference in the abundance of arbuscular mycorrhizae is due to greater plant cover (70 percent plant cover) in the organic systems, which use cover crops during the winter seasons, when compared to conventional corn-soybean rotations (40 percent plant cover) (Hepperly et al. 2007).

An analysis by Hole et al. (2005), which reviewed 76 comparative studies of organic versus conventional biodiversity, provided evidence that species abundance/richness across many taxa is generally higher in organic systems (Table 1). 
Table 1. Summary of the effects of organic farming on individual taxa in comparison to conventional.

\begin{tabular}{lccc}
\hline Taxon & Positive & Negative & Mixed/no difference \\
\hline Birds & 7 & & 2 \\
Mammals & 2 & & 1 \\
Butterflies & 1 & & 3 \\
Spiders & 7 & 2 & 4 \\
Earthworms & 7 & 5 & 3 \\
Beetles & 13 & 1 & 2 \\
Other arthropods & 7 & & 2 \\
Plants & 13 & & 8 \\
Soil microbes & 9 & 8 & 25 \\
Total & 66 & & \\
\hline
\end{tabular}

Source: Hole et al. (2005)

The three main contributors presented by Hole et al. (2005) that were most closely correlated with elevated biodiversity were "prohibition/reduced use of chemical pesticides and inorganic fertilizers, sympathetic management of non-crop habitats and field margins, and preservation of mixed farming (heterogeneity)."3

${ }^{3}$ Hole et al. (2005). Does organic farming benefit biodiversity? Biological Conservation Vol. 122. Pg. 113-130. 


\section{Energy Inputs}

\subsection{Background}

Agriculture systems, both organic and conventional, play an important role in current fossil fuel consumption and emission of greenhouse gases. When considering the entire production system of food from the farm to the grocery store, agriculture accounts for $19 \%$ of the fossil fuel energy use in the United States (Pimentel, 2006). The magnitude of inputs to farms has increased throughout the years as a way of pursuing methods to gain higher crop yields. Both forms of agriculture require similar amounts of fossil fuel for routine farm duties, such as pumping irrigation (when/where necessary), shipping costs for crops and seed, planting, and harvesting. However, there are significant differences in overall energy requirements and efficiencies between the two systems. These disparities lie largely in the energy requirements from manufacturing, shipping, and applications of pesticides and nitrogen-based fertilizers that organic farmers typically forego (Pimentel, 2006). In the pursuit of higher yields, conventional farming has increased the number of seeds planted per hectare, applied greater quantities of pesticides and nitrogen-based fertilizers, and has incorporated larger irrigation systems, all methods that drastically intensify the use of fossil fuels. The conventional approach, sometimes referred to as "industrial," is typically advantageous in times of cheap energy, as has been the case for several decades. The infrastructure that our main food supply was created under was during a time of very cheap and abundant fuel supplies. However, we are now in a time where 
energy efficiency is key, as we realize our limited global fossil fuel capacity, making these systems susceptible to rises in energy prices and future consequences to the planet. Coupled with using vast amounts of energy, figures from Smith et al. (2005) reported that agricultural land use contributes $12 \%$ of global greenhouse gas emissions (Vermeulen et al., 2012), potentially playing a large role in climate change.

\subsection{Difference of Inputs}

In the United States, the total fossil fuel energy amount used in conventional crop production is roughly 107 gallons per acre, which equals approximately $2 \mathrm{kcal}$ of fossil energy invested to harvest $1 \mathrm{kcal}$ of a crop (Pimentel, 2006). The largest energy sink in conventional farming is the application and production of nitrogen fertilizer. The production of the synthetic fertilizer is a major consumer of fossil fuel, as it takes anywhere from one to one and a half tons of petrol to produce one ton of the manufactured product (Soil Association, 2006; Ziesemer, 2007). On average, about 37 percent of the total energy expended in conventional farming practices are from pesticides and fertilizers, including phosphorous, and potassium (Soil Association, 2006). A research project completed by the British Ministry of Agriculture, Fisheries and Food reported the energy input per hectare in organic farming to be 65 percent of the energy input in conventional farming, 54 percent for potatoes, 50 percent for carrots, 40 percent for wheat, and 27 percent for broccoli (Cormack, 2000; Ziesemer, 2007). 
The long standing Farming Systems Trial at the Rodale Institute in Pennsylvania, reported significantly less fossil energy expenditures between their organic and conventional systems during the time period 1991 to 2000 (Hepperly et al. 2007). In the Farming Systems Trial, corn production spent about 5.2 million kcal of energy per ha for the conventional system. When weighed against the organic manure and organic legume systems, energy inputs were 28 percent (1.3 million kcal) and 32 percent (1.66 million kcal) less than that of the conventional system, respectively (Pimentel, 2005). However, there were similar results among the energy inputs between the organic manure, organic legume, and conventional systems for soybean production, where fossil fuel consumption was 2.3 million kcal, 2.3 million kcal, and 2.1 million kcal, respectively (Pimentel, 2005). Organic agriculture generally performs better in terms of energy efficiency (ratio of energy input per unit of crop output), because of its reliance on natural fertilizers (Ziesemer, 2007). In a study conducted by Stolze et al. (2000), increases in yield for conventional production over organic did not offset the energy used in the fertilizer to produce the observed gains. 


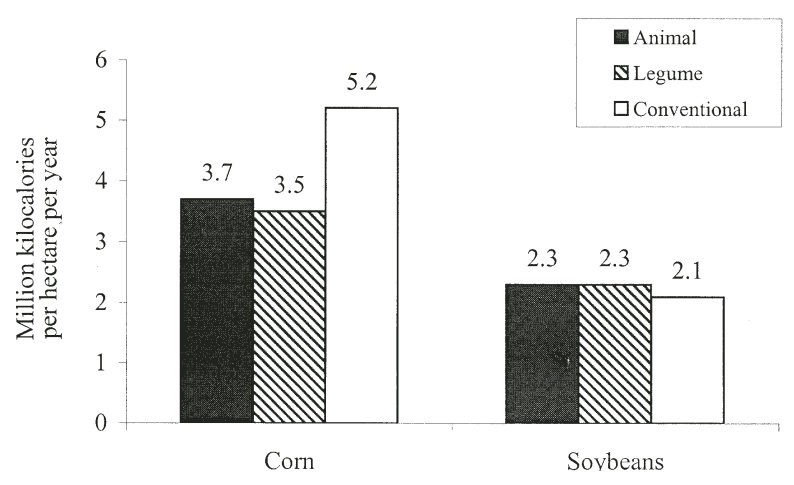

Figure 10. Average energy inputs between corn and soybean systems (in millions of kilocalories per hectare per year) in the three systems used in the Rodale Institute Farming Systems Trial from 1991 to 2000: organic animal-based cropping, organic legume-based cropping, and conventional cropping. Source: Pimentel et al. (2005)

There are still studies that need to be completed in order to fully realize the extent of energy use due to the difficulties in quantifying all of the areas in which fossil fuels are used. As far as on-farm consumption and use is concerned though, there are a few conclusions that can be drawn. Organic agriculture typically uses anywhere from 30 to 50 percent less energy in production than is observed in conventional farming. The reduced use of fossil energy in organic farming does come with an increase in human labor costs, about one third more than conventional under most circumstances (Ziesemer, 2007). With waning nonrenewable resources such as fossil fuels, shifts in more human-based labor may be an alternative to the current conventional methods. Because of its regulations, organic farming is an alternative and efficient way to decrease our fossil fuel consumption. 


\section{Conclusions}

Over the past century, there have been dramatic changes to our food system on and off the farm. The transition to resource intensive agriculture in the form of high fossil fuel, nitrogen, and other synthetic chemical use, helped to meet the first requirement of agriculture by providing sufficient productivity. However, this type of farming has neglected the needs of enhancing the natural-resource base and environment, making farming financially viable, and contributing to the well being of farming and their communities. The widely used conventional farming has been associated with lower soil fertility, excessive nitrate leaching, decreased biodiversity (both in the soil and aboveground organisms), and intensive fossil fuel use. It has been well-documented that farms using organic best management practices generally have healthier on-farm systems in terms of superior soil quality, greater biodiversity, lower fossil fuel costs, and less leaching from synthetic chemicals. The issue of whether or not organic farming can produce sufficient yields to meet our demands is one of the main arguments against using this as an alternative method to conventional farming. However, under best management practices the yields are often very similar and can even perform better in extreme conditions such as drought years (Hepperly et al. 2007). Under proper management practices and suitable environments, the implementation of organic farming can provide sufficient quantity and quality of food.

It is difficult to have a true comparison between organic and conventional agriculture due to how different the systems are and how they are managed. It is also difficult as they are not yet on an equal playing field as far as research is 
concerned. Conventional farming has received tremendously more research and financial support to get where the productivity is at today. There is much more that needs to be known about agriculture, not just in terms of organic or conventional farming, but also other methods as well, such as hybrid systems. In picking which way to go, organic or conventional, it is simply too difficult to choose just one or the other due to the pressures and needs of our society. It is clear however, that the future of our food system must meet the two challenges of feeding a growing population with high calorie diets, while simultaneously minimizing the impacts to our environment. The use of organic farming methods alone may not be the key, but they do offer advantages in terms of soil fertility, greater biodiversity, lower fuel costs, and less leaching from chemicals into surrounding ecosystems, and growing the implementation of them in our agricultural system can aid in meeting the objectives of agriculture. 


\section{REFERENCES}

Ahlenius, H. (2006). Agricultural land use distribution - croplands and pasture land. Global Environment Outlook 4 (GEO-4).

Badgley, C., Moghtader, J., Quintero, E., Zakem, E., Chappel, M.J., Aviles-Vazquez, K., Samulon, A., Perfecto. (2007). Organic agriculture and the global food supply. Renewable Agricultural Food System Vol. 22(2), pg. 86-108

Benton, T., Vickery, J., Wilson, J. (2003). Farmland biodiversity: is habitat heterogeneity the key? Trends in Ecology and Evolution. Vol. 18 No. 4. Pg. 182-188

Bot, A., Benites, J. (2005). The importance of soil organic matter. Key to drought-resistant soil and sustained food and production. Food and Agriculture Organization of the United States.

Ching, L. (2002). Organic Agriculture Fights Back. Institute of Science in Society. http://www.i-sis.org.uk/OrganicAgriculture.php

Coleman, P. (2012). Guide for Organic Crop Producers. United States Department of Agriculture. Pg. 4.

Cook, R.J. (1988). Biological control and holistic plant-health care in agriculture. American Journal of Alternative Agriculture. 3(2/3), 51-62.

Cormack, W.F. (2000). Energy use in organic farming systems. Ministry of Agriculture, Fisheries, and Food. Project code OF0182

Coulter, J.A., Nafziger, E.D., Wander, M.M. (2009). Soil Organic Matter Response to Crop System and Nitrogen Fertilization. Agronomy Journal Vol. 101: 592599.

Delate, K., Duffy, M., Chase, C., Holste, A., Friedrich, H., Wantat, N. (2003). An economic comparison of organic and conventional grain crops in a long-term agroecological research (LTAR) site in Iowa. American Journal of Alternative Agriculture, Vol. 18 (2): 59-69.

Delate, K., Cambardella, C.A. (2004). Agroecosystem performance during transition to certified organic grain production. Agronomy Journal 96:12881298.

Dobermann, A. (2012). Getting back to the field. Nature. Vol. 485. Pg 176-177. 
Drinkwater, L.E., Wagoner, P., Sarrantonio, M. (1998). Legume-based cropping systems have reduced carbon and nitrogen losses. Nature. Vol. 396, Pg. 262265.

Fan, T., Stewart, B.A., Payne, W., Yong, W., Luo, J., Gao, Y. (2005). Long-Term Fertilizer and Water Availability Effects on Cereal Yield and Soil Chemical Properties in Northwest China. Soil Science Society of America Journal 69: 842-855.

Scialabba, N.E. (2003). Organic agriculture: the challenge of sustaining food production while enhancing biodiversity. Natural Resources Management and Environment Department. http://www.fao.org/DOCREP/005/AD090E/AD090E00.HTM

Fuller, R.J., Gregory, R.D., Gibbons, D.W., Marchant, J.H., Wilson, J.D., Baillie, S.R., Carter, N. (1995). Population declines and range contractions among lowland farmland birds in Britain. Conservation Biolology. Vol. 9, Issue 6, Pg. 14251441

Gattinger, A., Muller, A., Haeni, M., Skinner, C., Fliessbach, A., Buchmann, N., Mader, P., Stolze, M., Smith, p., Scialabba, N., Niggli, U. (2012). Enhanced top soil carbon stocks under organic farming. Proceedings of the National Academy of Sciences. Vol. 109. No 44. 18226-18231.

Hepperly, P., Seidel, R., Pimentel, D., Hanson, J., Douds Jr., D. (2007). Organic Farming Enhances Soil Carbon and its Benefits. In: Kimble, Rice, Read, Mooney, Follet, and Lal. Soil Carbon Management, Economic, Environmental and Societal Benefits, CRC Press. Pg. 129-149.

Hoitink, H.A.J., Inbar, Y., Boehm, M.J. (1991). Status of compost-amended potting mixes naturally suppressive to soilborne diseases of floricultural crops, Plant Dis., 75(9), 869-873.

Hole, D.G., Perkins, A.J., Wilson, J.D., Alexander, I.H., Grice, P.V., Evans, A.D. (2005). Does organic farming benefit biodiversity? Biological Conservation Vol. 122, Pg. 113-130.

Horlings, L.G., Marsden, T.K. (2011). Towards the real green revolution? Exploring the conceptual dimensions of a new ecological modernization of agriculture that could 'feed the world'. Global Environmental Change, Vol. 21, Pg 441452.

International Federation of Organic Agriculture Movements. (2008). Organic Agriculture for the real Green Revolution in Africa. 
http://infohub.ifoam.org/sites/default/files/page/files/agra_greenrevolutio n_en.pdf

Kahl, H. (2004). Role and Importance of nitrogen in your soil. Organic New Zealand Magazine. Soil and Health Association of New Zealand Inc. http://www.organicnz.org.nz/node/153

Krebs, J.R., Wilson, J., Bradbury, R., Siriwardena, G. (1999). The second silent spring? Nature. Vol. 400, Pg. 611-612.

Lampkin, N., Measures, M., (1995). 1995/96 Organic Farm Management Handbook. University of Wales Elm, Farm Research Centre, Aberystwyth.

Lal R. (2004). Soil carbon sequestration impacts on global climate change and food security. Science 304:1623-1627.

Leifeld, J. (2012). How Sustainable is organic farming? Agriculture, Ecosystems and and Environment. Vol. 150, Pg. 121-122

Liebhardt, B. (2001). "Get the facts straight: organic agriculture yields are good," Organic Farming Research Foundation. Information Bulletin \#10.

Maeder, P., Fliebbbach, A., Dubois, D., Gunst, L., Fried, P., and Niggli, R. (2002). Soil fertility and biodiversity in organic farming. Science Vol. 296, Pg. 1694-1697.

Marriott, E.E., Wander, M.M. (2006). Total and labile soil organic matter in organic and conventional farming systems. Soil Science Society of America Journal Vol. 70, Pg. 950-959.

Merberg, A. (2013). An Unlikely Fix: nitrogen fertilizer and organic agriculture. Biology Fortified. http://www.biofortified.org/2013/04/an-unlikely-fix-nitrogen-fertilizerand-organic-agriculture/

Mikkelsen, R., Hartz, T.K. (2008). Nitrogen Sources for Organic Crop Production. Better Crops. Vol. 92 No. 4. Pg. 16-19.

Mingle, J. (2013). A Dangerous Fixation: Synthetic nitrogen was born 100 years ago; it's why half of us are alive. Slate. March 12, 2013. http://www.slate.com/articles/health_and_science/the_efficient_planet/201 3/03/nitrogen_fixation_anniversary_modern_agriculture_needs_to_use_fertili zer.single.html

National Research Council. (2010). Toward sustainable agricultural systems in the $21^{\text {st }}$ century. Washington, DC: The National Academies Press. Pg. 1. 
O’Leary, M., Rehm, G., Schmitt, M. (1994). Understanding Nitrogen in Soils. University of Minnesota. http://www.extension.umn.edu/distribution/cropsystems/dc3770.html

Omokanye, A.T., Kelleher, F.M., and McInnes, A. (2011). Low-Input Cropping Systems and Nitrogen Fertilizer Effects on Crop Production: Soil Nitrogen Dynamics and Efficiency of Nitrogen Use in Maize Crop. American-Eurasian Journal of Agriculture and Environmental Science. Vol. 11 (2), Pg. 282-295.

Parrott, N., Marsden, T. (2002). The Real Green Revolution. Organic and Agroecological Farming in the South. Greenpeace Environment Trust. Pg. 24111

Pimentel, D., Hepperly, P., Hanson, J., Douds, D., Seidel, R. (2005) Environmental, Energetic, and Economic Comparisons of Organic and Conventional Farming Systems. BioScience. Vol. 55 No. 7. Pg. 573-582.

Pimentel, D., Stachow, U., Takacs, D.A., Brubaker, H.W., Dumas, A.R., Meaney, J.J., O'Neil, J., Onsi, D.E., and Corzilius, D.B. (1992). Conserving biological diversity in agricultural/ forestry systems, BioScience, 42, 354-362.

Pimentel, David. (2006). Impacts of Organic Farming on the efficiency of Energy Use in Agriculture: An Organic Center State of Science Review. The Organic Sector. Pg. 1-39.

Porter, P.M., Huggins, D.R., Perillo, C.A., Quiring, S.R., and Crookston, R.K. (2003). Organic and other management strategies with two- and four-year crop rotations in Minnesota. Agronomy Journal Vol. 95 Pg. 233-244.

Posner, J.L., Baldock, J.O., and Hedtcke, J.L. (2008). Organic and conventional production systems in the Wisconsin Integrated Cropping Systems Trials. I. Productivity 1990- 2002. Agronomy Journal Vol. 100, Pg. 253-260.

Reganold, John P. (2012). Fruits of Organic Farming. Nature. Vol. 485 Pg. 176.

Rigby, D., Caceres, D. (2001). Organic farming and the sustainability of agricultural systems. Agricultural Systems. Vol. 68, Pg. 21-40.

Seufert, V., Ramankutty, N. Foley, J.A. (2012). Comparing the yields of organic and conventional agriculture. Nature. Vol. 485, Pg. 229-232.

Smith, P., Martino, D., Cai, Z., Gwary, D. Janzen, H., Kumar, P., McCarl, B., Ogle, S., O'Mara, F., Rice, C., Scholes, B., Sirotenko, O., Howden, M., McAllister, T., Pan,G., Romanenkov, V., Schneider, U., Towprayoon, S. (2007). Policy and 
technological constraints to implementation of greenhouse gas mitigation options in agriculture. Agriculture Ecosystems and Environment. Vol. 118, Issue 1-4, Pg. 6-28.

Soil Association. (2006). Organic Works: Providing more jobs through organic farming and local food supply. Bristol House, Bristol.

Stolze, M., Piorr, A., Häring, A., Dabbert, S. (2000). "The Environmental Impacts of Organic Farming in Europe." Organic Farming in Europe: Economics and Policy, Volume 6. University of Hohenheim Department of Farm Economics, Stuttgart.

Sutton, M.A., Bleeker, A., Howard, C.M. Bekunda, M., Grizzetti, B., Vries, W. de, van Grinsven, H.J.M., Abrol, Y.P., Adhya, T.K., Billen, G., Davidson, E.A., Datta, A., Diaz, R., Erisman, J.W., Liu, X.J., Oenema, O., Palm, C., Raghuram, N., Reis, A., Scholz, R.W., Sims, T., Westhoek, H., Zhang, F.S. (2013). Our Nutrient World: the challenge to produce more food and energy with less pollution. Gloval Overview of Nutrient Management. Centre for Ecology and Hydrology, Edinburgh on behalf of the Global Partnership on Nutrient Management and the International Nitrogen Initiative. http://initrogen.org/index.php/publications/our-nutrient-world/

United States Census Bureau. (2013). International Data Base. http://www.census.gov/population/popwnotes.html

Vermeulen, S.J., Campbell, B.M., Ingram, J.S. (2012) Climate Change and Food Systems. Annual Review of Environment and Resources. Vol. 37. Pg. 195-222

Willer, H., Kilcher, L. (2011). In The World of Organic Agriculture: Statistics and Emerging Trends 2011. International Federation of Organic Agriculture Movements and Research Insititute of Organic Agriculture. Pg. 26-32

Wortman, S.E., Galusha, T.D., Mason, S.C., Francis, C.A. (2011). Soil fertility and crop yields in long-term organic and conventional cropping systems in Eastern Nebraska. Renewable Agriculture and Food Systems. Vol. 27, Pg. 200-216

Ziesemer, J. (2007). Energy Use In Organic Food Systems. Natural Resources Management and Environment Department Food and Agriculture Organization of the United Nations. 